\title{
HPLC Analytical Method Validation for Determination of Cefotaxime in the Bulk and Finished Pharmaceutical Dosage Form
}

\author{
Mostafa F. Al-Hakkani \\ Chemistry Department, Faculty of Science, New Valley University, Al-Kharja 72511, Egypt \\ Email: mostafa.f@scinv.au.edu.eg
}

\begin{abstract}
Cefotaxime (Cfm) is a member of the third generation of the Cephalosporin antibiotics. It used on a wide scale in prescribed antibiotic drugs as anti-infection for gram-positive microorganisms and gram-negative microorganisms. The present study aimed to develop an HPLC method of Cfm analysis enjoyed highly linearity, repeatability, robustness, ruggedness, selectivity, rapidly and economical to use. The chromatographic method uses a reversed phase column BDS column (150 mm x $4.0 \mathrm{~mm} \times 5 \mu \mathrm{m})$. The mobile phase was prepared by mixing Methanol: Phosphate buffer $(1000 \mathrm{~mL}: 130 \mathrm{~mL})$ and the $\mathrm{pH}$ was adjusted to 6.15 at isocratic flow rate 1.0 $\mathrm{mL} / \mathrm{min}$ with PDA detector at $235 \mathrm{~nm}$, column oven adjusted at $30^{\circ} \mathrm{C}$ and injection volume $20 \mu \mathrm{L}$. The method revealed that satisfied linearity regression $\mathrm{R}^{2}(0.9992)$ with repeatability $(0.15 \%)$ with $\mathrm{DL}$ and $\mathrm{QL} ; 35.5 \mathrm{ng} / \mathrm{mL}$ and $107.6 \mathrm{ng} / \mathrm{mL}$ respectively. The method showed a successful application of analytical method validation for $\mathrm{Cfm}$ in bulk and pharmaceutical formulations.

Keywords: cefotaxime, HPLC, validation, pharmaceutical
\end{abstract}

$\begin{array}{ll}\text { Abbreviations } & \\ \text { Cfm } & \text { Cefotaxime } \\ \text { HPLC } & \text { High-performance liquid chromatography. } \\ \text { PDA } & \text { Photodiode array detector } \\ \text { UV } & \text { Ultraviolet } \\ \text { EP } & \text { European Pharmacopeia } \\ \text { USP } & \text { United States Pharmacopeia } \\ \text { DL } & \text { Detection limit } \\ \text { QL } & \text { Quantitation limit } \\ \text { Conc } & \text { Concentration } \\ \text { P. A } & \text { Peak area } \\ \text { P. As } & \text { Peak areas } \\ \text { STDEV } & \text { Standard deviation } \\ \text { RSD } & \text { Relative standard deviation }\end{array}$

\section{Introduction}<smiles>[R]C(=O)N[C@@H]1C(=O)N2C(C(=O)O)=C([R])CS[C@H]12</smiles><smiles>CO/N=C(\C(=O)N[C@@H]1C(=O)N2C(C(=O)O)=C(COC(C)=O)CS[C@H]12)c1csc(N)n1</smiles>

Figure 1. Structure of Cephalosporins $\beta$-lactam core ring (A) and Cefotaxime (B) 
The IUPAC name of Cfm is Cefotaxime sodium salt of (6R,7R)-3[(acetyloxy)methyl]-7-[[(2Z)-2-(2-aminothiazol4-yl)-2-(methoxyimino)acetyl]amino]8-oxo-5-thia1-azabicyclo[4.2.0]oct-2-ene-2-carboxylate ${ }^{[1]}$. Cfm is a member of the third generation of the Cephalosporin antibiotics. Cfm contains the Cephalosporins $\beta$-lactam core ring as shown in Figures $1 \mathrm{~A}, \mathrm{~B}$.

It used to treat many and various bacterial infections and it has excellent activity against many pathogens as, Enterobacteriaceae, Anaerobes, Gram-negative class such as Haemophilus influenzae, Branhamella Catarrhalis, Escherichia coli, Neisseria gonorrhoeae, klebsiella, Serratia marcescens, Haemophilus, Providencia, and Meningococcus including strains of $\beta$-lactamase producing. It works by killing bacteria and it has an analytically and clinically significant due to its broad spectrum as stability and antimicrobial activity ${ }^{[2]}$.

Several analytical methods have been developed to determine Cfm in different pharmaceutical dosage forms. These methods include different analysis techniques as microbiological methods and high-performance liquid chromatography (HPLC) ${ }^{[3]}$.

Cfm has been quantitatively analyzed in bulk material and different pharmaceutical dosage forms by infrared spectroscopy ${ }^{[4]}$, spectrophotometric determination ${ }^{[5-9]}$, Voltammetric determination ${ }^{[10]}$, HPLC-MS ${ }^{[11]}$. Mass spectrometric methods may have the highest sensitivity, but the determination process is complicated to use and very expensive.

Chromatographic separation technique is one of the most convenient, essential, easiest and powerful in most qualitative and quantitative analysis. HPLC is currently the most satisfying tool for an excellent and optimum separation ${ }^{[2,}$ 12-14].

In the present study, an HPLC method with a photodiode array detector (PDA) was developed for the determination of a lower concentration of $\mathrm{Cfm}$ in different pharmaceutical dosage forms. The proposed analytical method of Cfm was found to be precise, repeatable, linear, accurate, rugged, robust, specific, selective and economic.

\section{Experimental}

\subsection{Materials and chemicals}

Cefotaxime sodium standard (963 $\mu \mathrm{g} / \mathrm{g}$ ) was supplied by Zhuhai United Laboratories co. Ltd (India) as a gift sample from Smart pharma (Assuit, Egypt). Methanol HPLC-grade, Sodium dihydrogen phosphate anhydrous, Hydrochloric acid, Phosphoric acid 85\%, Sodium hydroxide and Hydrogen peroxide (Scharlau, Spain). Deionized water used in the analysis was prepared by reverse osmosis and passed through a $0.45 \mu \mathrm{m}$ Millipore filter (Millipore Company, USA) before use. Phosphate buffer was prepared by weighing about 7.1 of disodium hydrogen phosphate anhydrous and dissolved in 1000 $\mathrm{mL}$ deionized water.

\subsection{Chromatographic system}

Cfm was measured using the LC-20A HPLC instrument with the PDA (Shimadzu, Japan).

The method was performed on isocratic RP mode using the BDS column $(150 \mathrm{~mm} \times 4.0 \mathrm{~mm} \times 5 \mu \mathrm{m})($ Thermo Scientific, USA). The mobile phase was prepared by mixing $130 \mathrm{~mL}$ of Methanol and $1000 \mathrm{~mL}$ of Phosphate buffer and the $\mathrm{pH}$ was adjusted to 6.15 . Flow rate $1.0 \mathrm{~mL} / \mathrm{min}$ with PDA detector at $235 \mathrm{~nm}$, column oven adjusted at $30^{\circ} \mathrm{C}$ and injection volume $20 \mu \mathrm{L}$.

\subsection{Standard solution preparation}

An accurately weighed quantity of Cfm $(10 \mathrm{mg})$ was transferred to a $1000 \mathrm{~mL}$ volumetric flask, approximately 100 $\mathrm{mL}$ of deionized water was added and dissolved in the ultrasonic bath. The solution was completed to the marked volume using deionized water, mixed and further diluted to obtain a final concentration of $1 \mu \mathrm{g} / \mathrm{mL}$.

\subsection{Parameters of method validation}

The validation of HPLC method was carried out according to International Conference on Harmonization (ICH), Food and Drug Administration (FDA), United States of American Pharmacopoeia (USP) and European Pharmacopoeia (EP) guidelines with respect to parameters including tuning system and suitability of the system, Range linearity, detection limit, quantification limit, repeatability, recovery and accuracy, robustness, ruggedness, the stability of the solution, specificity, and selectivity ${ }^{[15-20]}$.

Method validation became a vital and significant demand in each analysis method to assure the result reliability and reproducibility at any time for anyone in all scientific research fields ${ }^{[21]}$.

\subsection{Tuning system and suitability of the system}

At first, we should assure the suitability of the chromatographic system and the instrument performance. 
The standard tuning solution was prepared in deionized water to obtain the final concentration $1 \mu \mathrm{g} / \mathrm{mL}$.

\subsection{Range \& linearity}

Linearity is defined by the correlation coefficient, which should be $\geq 0.999^{[15-20]}$, using peak area (P.A) responses, where the range included the concentrations between the minimum and the maximum concentration in linearity test.

Regression linearity equation:

P.A $=\mathrm{a}($ Conc. $)+\mathrm{b}$

Where, (P.A) presents Peak area, (Conc.) presents the concentration $(\mu \mathrm{g} / \mathrm{mL})$, a is the slope and $\mathrm{b}$ is the intercept.

Linearity was performed by preparing 7 different concentrations of $(0.5 \mu \mathrm{g} / \mathrm{mL}, 0.7 \mu \mathrm{g} / \mathrm{mL}, 0.9 \mu \mathrm{g} / \mathrm{mL}, 1 \mu \mathrm{g} / \mathrm{mL}, 1.1 \mu \mathrm{g} /$ $\mathrm{mL}, 1.3 \mu \mathrm{g} / \mathrm{mL}$ and $1.5 \mu \mathrm{g} / \mathrm{mL}$ ) of Cfm standard. The sample was prepared by weighing about $100 \mathrm{mg}$ of Cfm standard and dissolved in $1000 \mathrm{~mL}$ of the mobile phase in a volumetric flask (stock solution). Subsequently, serial dilutions were prepared from the stock solution to obtained the final concentrations. Finally, the diluted solutions were injected in triplicates.

\subsection{Detection limit (DL)}

It was defined as the smallest concentration of an analyte in the sample which can be detected by the detector and it is not significant to undergo the linearity and precision test (it is not to be quantified) ${ }^{[15-20]}$.

\subsection{Quantitation limit (QL)}

It was defined as the smallest concentration of an analyte in the sample which can be detected by the detector and it can be determined quantitatively with appropriate precision and accuracy ${ }^{[15-20]}$.

DL and QL were calculated according to the linearity of the calibration curve and its standard error according to the following equations:

$$
\begin{aligned}
& \mathrm{DL}=3.3 \sigma / \mathrm{S} \\
& \mathrm{QL}=10 \sigma / \mathrm{S}
\end{aligned}
$$

Where $\sigma$ : is the standard error and $\mathrm{S}$ : is a slope of the linearity calibration curve.

\subsection{Recovery and accuracy}

Recovery and accuracy, each of them is used interchangeably. The accuracy of a measurement is defined as the closeness of the measured value (actual conc) to the true value (Theoretical conc), where recovery is defined as how much was recovered from the initial concentration using the purposed method ${ }^{[15-20]}$.

Accuracy and recovery can be conducted using the addition of three standard sets of $\mathrm{Cfm}$ to get final concentration at $[0.8 \mu \mathrm{g} / \mathrm{mL}],[1 \mu \mathrm{g} / \mathrm{mL}]$ and $[1.2 \mu \mathrm{g} / \mathrm{mL}]$. Finally, the concentration was increased using the addition of $[0.1 \mu \mathrm{g} / \mathrm{mL}]$ of $\mathrm{Cfm}$ and injected in triplicate for each concentration. The average P. As for each concentration was calculated. The actual concentration for each average P. As from the linearity equation was calculated, then the recovery was calculated according to the following equation:

Recovery $\%=$ Actual Conc. $\mu \mathrm{g} / \mathrm{mL} /$ Theoretical Conc. $\mu \mathrm{g} / \mathrm{mL} \times 100$

\subsection{Precision and repeatability}

Repeatability expresses "The precision under the same operating conditions over a short interval of time. Repeatability is also termed intra-assay precision" ${ }^{[15-20]}$.

Repeatability was conducted using 6 different preparations of the test concentration $[1 \mu \mathrm{g} / \mathrm{mL}]$ of Cfm.

\subsection{Robustness}

Robustness was determined by observing how a method stands up to slight variations ${ }^{[15-20]}$ in normal operating parameters. This could be a slight variation in mobile phase composition, flow rate, $\mathrm{pH}$, temperature and etc.

The analytical method validation was performed by deliberate changes in the target method parameters. Changes included a different organic solvent (Methanol) ratio at $\pm 10 \%$, flow rate $\pm 0.005 \mathrm{~mL} / \mathrm{min}, \mathrm{pH} \pm 0.5$ unit and temperature $\pm 2 \square$ C. where the other method parameters were kept constant in each study.

The robustness of the method can be evaluated by calculation of the pooled RSD\% of the total number of replicates 
that have been made in each parameter change.

\subsection{Ruggedness}

The ruggedness of an analytical method is the degree of reproducibility ${ }^{[15-20]}$ of the test results obtained by the analysis of the same samples under a variety of conditions. The major change such as different analysts, HPLC columns of different serial numbers or different suppliers, different days and etc.

\subsection{Stability of solution}

This test was conducted by injection the test at the target concentration of $[1 \mu \mathrm{g} / \mathrm{mL}]$. It was injected at different intervals of time to assess the solution stability. The solution was kept at 2-8 $\square \mathrm{C}$ after each injection.

\subsection{Specificity and Selectivity}

Selectivity means the ability to measure accurately an analyte in the presence of interference ${ }^{[15-20]}$. It was performed by separate injection of a blank solution (deionized water), $\mathrm{Cfm}$ standard and formula solutions with $\mathrm{Cfm}$ at the same test target concentration $1 \mu \mathrm{g} / \mathrm{mL}$. Also, specificity was performed using forced degradation to provide an indication of the stability-indicating properties of the procedure and indicating the absence of other interference with a good separation of analyte principle peak ${ }^{[15-20]}$.

Heating degradation of Cfm: It was performed by weighing about $10 \mathrm{mg}$ in $1000 \mathrm{~mL}$ volumetric flask and completed with deionized water then boiled under reflux for 5 minutes, allowed to coll. Then it was injected onto HPLC after dilution to final concentration $1 \mu \mathrm{g} / \mathrm{mL}$ of cefotaxime from the claimed starting solution concentration.

\subsection{Heating degradation of $\mathrm{Cfm}$}

It was performed by weighing about $10 \mathrm{mg}$ in $1000 \mathrm{~mL}$ volumetric flask and completed with deionized water then boiled under reflux for 5 minutes, allowed to coll. Then it was injected onto HPLC after dilution to final concentration 1 $\mu \mathrm{g} / \mathrm{mL}$ of cefotaxime from the claimed starting solution concentration.

\subsection{Acid hydrolysis}

It was performed by weighing about $10 \mathrm{mg}$ of in $1000 \mathrm{ml}$ volumetric flask and dissolved in $950 \mathrm{~mL}$ of deionized water then a $50 \mathrm{~mL}$ of $\mathrm{HCl} 0.1 \mathrm{~N}$ was added and left for 15 minutes, then neutralized and injected onto HPLC after dilution to final concentration $1 \mu \mathrm{g} / \mathrm{mL}$ of cefotaxime from the claimed starting solution concentration.

\subsection{Base hydrolysis}

It was performed by weighing about $10 \mathrm{mg}$ of in $1000 \mathrm{~mL}$ volumetric flask and dissolved in $950 \mathrm{~mL}$ of deionized water then a $50 \mathrm{~mL}$ of $\mathrm{NaOH} 0.1 \mathrm{~N}$ was added and left for 15 minutes, then neutralized and injected onto HPLC after dilution to final concentration $1 \mu \mathrm{g} / \mathrm{mL}$ of cefotaxime from the claimed starting solution concentration.

\subsection{Oxidation hydrolysis}

It was performed by weighing about $10 \mathrm{mg}$ of in $1000 \mathrm{~mL}$ volumetric flask and dissolved in $950 \mathrm{~mL}$ of deionized water then add $50 \mathrm{~mL}$ of $\mathrm{H}_{2} \mathrm{O}_{2} 3 \%$ and left for 15 minutes, then neutralized and injected onto HPLC after dilution to final concentration $1 \mu \mathrm{g} / \mathrm{mL}$ of cefotaxime from the claimed starting solution concentration.

Note: The neutralization performed to obtain a $\mathrm{pH}$ of solution equal to 7.0 using acid for base and vis inverse or using potassium permanganate.

\subsection{Application of the validated test method for $\mathrm{Cfm}$ analysis in analysis of different human- finished pharmaceutical drugs in the Egyptian local market}

Claforan $1 \mathrm{gm}$ vials (Sanofi) and Cefotax $1 \mathrm{gm}$ vials (Eipico) were tested using the validated method of $\mathrm{Cfm}$.

\section{Results and discussion}

\subsection{Tuning system and suitability of the system}

The retention time of Cfm. peak appeared about at 12.5 minutes as in Figure 2, also the RSD \%, tailing and plates evaluated as in Table 1. The RSD \% for each parameter of system suitability was found to be $<2.0 \%$ for 6 replicates according to the requirements in $\mathrm{EP}^{[15-20]}$. 


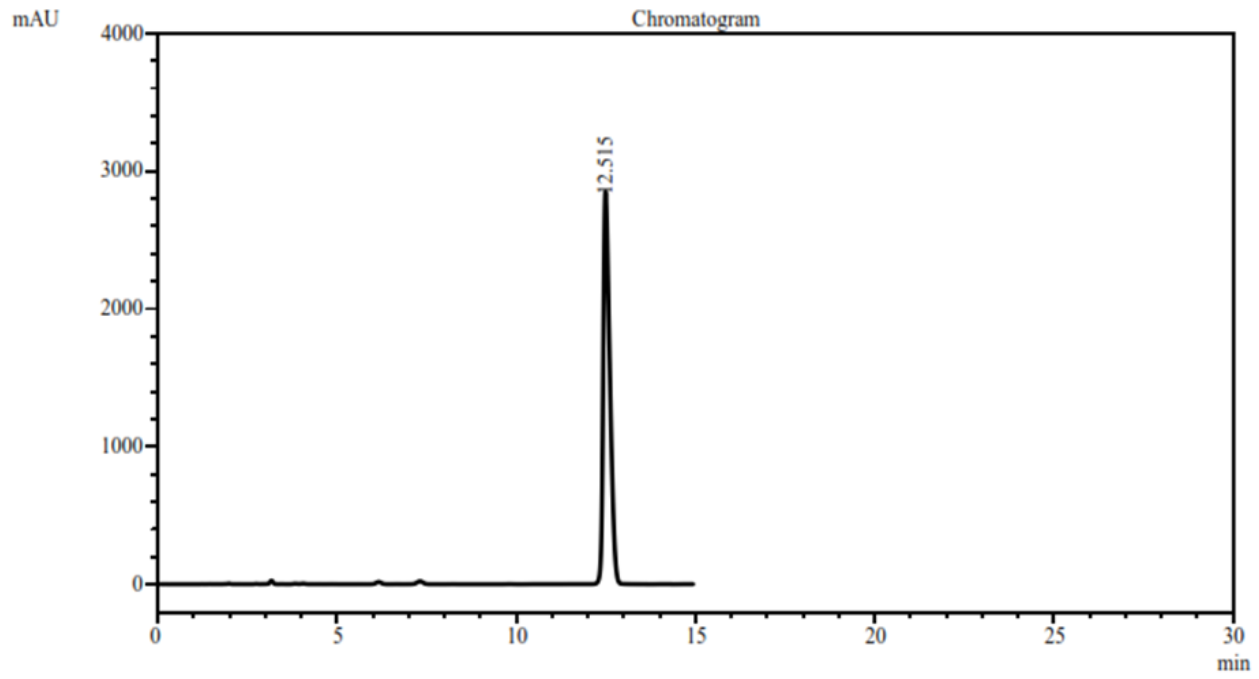

Figure 2. Cfm chromatogram

Table 1. Tuning system and suitability of the system

\begin{tabular}{cccc}
\hline Replicate \# & P. A & Tailing & Plates \\
\hline 1 & 19781.6 & 1.768 & 15257 \\
2 & 19736.8 & 1.768 & 15328 \\
3 & 19712.7 & 1.767 & 15212 \\
4 & 19689.4 & 1.768 & 15298 \\
5 & 19663.0 & 1.768 & 15475 \\
6 & 19626.5 & 1.768 & 15308 \\
RSD $\%$ & $0.28 \%$ & $0.02 \%$ & $0.58 \%$ \\
\hline
\end{tabular}

\subsection{Range \& linearity}

\section{Linearity calibration curve of Cefotaxime}

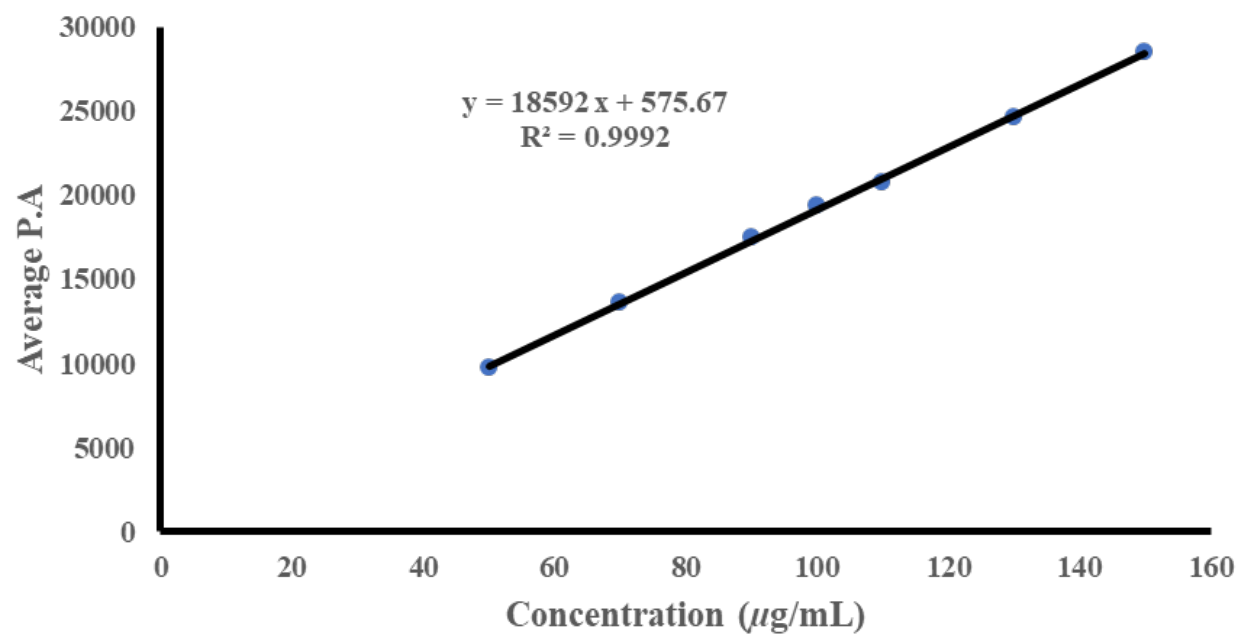

Figure 3. Linearity calibration curve of $\mathrm{Cfm}$; the chromatographic method is a reversed-phase column BDS column (150 mm $\mathrm{x} 4.0 \mathrm{~mm} x \mathbf{5 m})$. The mobile phase was prepared by mixing Methanol: Phosphate buffer (1000 mL:130 mL) and the pH was adjusted to 6.15 at isocratic flow rate 1.0 $\mathrm{mL} / \mathrm{min}$ with PDA detector at $235 \mathrm{~nm}$, column oven adjusted at $30^{\circ} \mathrm{C}$ and injection volume $20 \mu \mathrm{L}$, target conc $1 \mu \mathrm{g} / \mathrm{mL}$ of $\mathrm{Cfm}$

It's clear from the output results that, the method is linear in the range 0.5 to $1.5 \mu \mathrm{g} / \mathrm{mL}$ from the target conc $1 \mu \mathrm{g} / \mathrm{mL}$. Calibration curve of Cfm showed also, a good regression coefficient $\mathrm{R}^{2}$ as shown in Figure 3 \& Table 2 which show the linear proportional between the response of P. As and the corresponding concentrations. So, the method was found to be linear as the $\mathrm{R}^{2}$ was $0.9992 \geq 0.999$ and the curve follows the linear equation: $\mathrm{P} . \mathrm{A}=18592(\mathrm{Conc})+575.67$. 
Table 2. Linearity data and parameters of $\mathrm{Cfm}$ calibration curve

\begin{tabular}{|c|c|c|c|}
\hline Conc $(\mu \mathrm{g} / \mathrm{mL})$ & Average P. As & Statistical data & \\
\hline 0.5 & 9746.4 & $\mathrm{R} 2$ & 0.9992 \\
\hline 0.7 & 13637.2 & Slope & 18592 \\
\hline 0.9 & 17498.9 & Intercept & 575.67 \\
\hline 1.0 & 19386.7 & Standard error & 200.09 \\
\hline 1.1 & 20752.9 & & \\
\hline 1.3 & 24613.6 & & \\
\hline 1.5 & 28538.7 & & \\
\hline
\end{tabular}

\subsection{DL and QL}

DL and QL values were calculated from the linearity calibration curve data of Cfm and they found to be $35.5 \mathrm{ng} /$ $\mathrm{mL}$ and $107.6 \mathrm{ng} / \mathrm{mL}$ for DL and QL respectively. These values have been indicated on the method sensitivity at lower concentrations.

\subsection{Accuracy and recovery}

The results revealed that the method was found to be accurate within the range from $98 \%$ to $102 \%$ of $\mathrm{Cfm}$ as shown in Table 3.

Table 3. Recovery and accuracy

\begin{tabular}{cccc}
\hline Theoretical conc $(\mu \mathrm{g} / \mathrm{mL})$ & Average P. As & Actual conc $(\mu \mathrm{g} / \mathrm{mL})$ & Recovery $\%$ \\
\hline $0.8+0.1$ & 17290.9 & 0.899 & $99.9 \%$ \\
$1.0+0.1$ & 21071.2 & 1.102 & $100.2 \%$ \\
$1.2+0.1$ & 24769.1 & 1.301 & $100.1 \%$ \\
\hline
\end{tabular}

\subsection{Repeatability}

Repeatability of the standard was expressed using RSD\% of P. As shown in Table 4.

The obtained RSD $\%$ of the 6 samples preparations was found to be $0.15 \% \leqslant 2.0 \%$ according to repeatability requirements in $\mathrm{EP}^{[15-20]}$.

This revealed that the method was precise and repeatable.

\begin{tabular}{cccc}
\multicolumn{5}{c}{ Table 4. Repeatability } \\
\hline$\#$ & Sample P. A & \multicolumn{2}{c}{ Statistical data } \\
\hline 1 & 19259.5 & Average P. As & 19274.6 \\
2 & 19273.7 & STDEV & 28.4 \\
3 & 19320.8 & RSD $\%$ & $0.15 \%$ \\
4 & 19289.1 & & \\
5 & 19267.1 & & \\
6 & 19237.2 & & \\
\hline
\end{tabular}

\subsection{Robustness}

The results of deliberated changes included organic solvent ratio in the mobile phase ( $\pm 10 \%$ ), temperature $\pm 2 \square \mathrm{C}$, flow rate $\pm 0.005 \mathrm{~mL} / \mathrm{min}$ and $\mathrm{pH} \pm 0.5$ unit. were evaluated by RDS \% calculations. The observed RSD \% results were $0.84 \%, 0.99 \%, 0.39 \%$ and $0.59 \%$ for each change in organic ratio, temperature degree, flow rate, and mobile phase $\mathrm{pH}$ respectively.

Overall, in each parameter change; the RSD \% was $<2 \%$ as shown in Tables $5,6,7$ and 8 . So, the obtained results indicating that the method is robust. 
Table 5. Organic solvent ratio in the mobile phase change effect $130 \mathrm{~mL} \pm \mathbf{1 0} \%$

\begin{tabular}{cccc}
\hline Replicate \# & $130 \mathrm{~mL}$ & $143 \mathrm{~mL}$ & $117 \mathrm{~mL}$ \\
\hline 1 & 19781.6 & 19450.0 & 19418.9 \\
2 & 19736.8 & 19371.8 & 19397.6 \\
3 & 19712.7 & 19356.1 & 19394.9 \\
4 & 19689.4 & 19341.9 & 19398.1 \\
5 & 19663.0 & 19339.8 & 19371.1 \\
6 & 19626.5 & 19308.2 & 19356.8 \\
Pooled mean & 19484.2 & & \\
Pooled RSD\% & $0.84 \%$ & &
\end{tabular}

Table 6. Temperature change effect $30 \square \mathrm{C} \pm 2 \square \mathrm{C}$

\begin{tabular}{cccc}
\hline Replicate \# & $30 \square \mathrm{C}$ & $32 \square \mathrm{C}$ & $28 \square \mathrm{C}$ \\
\hline 1 & 19781.6 & 19568.9 & 19356.1 \\
3 & 19736.8 & 19505.8 & 19307.8 \\
4 & 19712.7 & 19468.7 & 19282.1 \\
5 & 19689.4 & 19447.5 & 19266.2 \\
6 & 19663.0 & 19407.9 & 19217.6 \\
Pooled mean & 19626.5 & 19373.9 & 19174.5 \\
Pooled RSD\% & 19477.1 & & \\
\hline
\end{tabular}

Table 7. Flow rate change effect $1 \mathrm{~mL} / \mathrm{min} \pm 0.005 \mathrm{~mL} / \mathrm{min}$

\begin{tabular}{|c|c|c|c|}
\hline Replicate \# & $1 \mathrm{~mL} / \mathrm{min}$ & $0.995 \mathrm{~mL} / \mathrm{min}$ & $1.005 \mathrm{~mL} / \mathrm{min}$ \\
\hline 1 & 19781.6 & 19691.2 & 19728.4 \\
\hline 2 & 19736.8 & 19642.3 & 19687.9 \\
\hline 3 & 19712.7 & 19579.4 & 19635.8 \\
\hline 4 & 19689.4 & 19601.7 & 19593.3 \\
\hline 5 & 19663.0 & 19521.5 & 19562.5 \\
\hline 6 & 19626.5 & 19496.0 & 19608.0 \\
\hline Pooled mean & 19642.1 & & \\
\hline Pooled RSD\% & $0.39 \%$ & & \\
\hline \multicolumn{4}{|c|}{ Table 8. pH change effect at pH $6.25 \pm 0.5$ unit } \\
\hline Replicate \# & pH 6.25 & $\mathrm{pH} 5.75$ & $\mathrm{pH} 6.75$ \\
\hline 1 & 19781.6 & 19556.8 & 19502.5 \\
\hline 2 & 19736.8 & 19544.0 & 19506.4 \\
\hline 3 & 19712.7 & 19539.6 & 19473.1 \\
\hline 4 & 19689.4 & 19525.1 & 19413.2 \\
\hline 5 & 19663.0 & 19514.8 & 19442.2 \\
\hline 6 & 19626.5 & 19468.4 & 19394.4 \\
\hline Pooled mean & 19560.6 & & \\
\hline Pooled RSD\% & $0.59 \%$ & & \\
\hline
\end{tabular}

\subsection{Ruggedness}

According to the obtained results after major changes application on the analysis method including day-to-day, analyst-to-analyst, and column-to-column precisions. The method was found to be rugged as revealed results in Tables 9,10 and 11 . The ruggedness of method was evaluated using RSD \% and it was $0.95 \%, 0.28 \%$ and $1.3 \%$ for day-to-day, analyst-to-analyst, and column-to-column precisions respectively and also as in robustness challenge all the RSD $\%<2.0 \%$. 
Table 9. Day change effect against the second \& third day

\begin{tabular}{|c|c|c|c|}
\hline Replicate \# & First day & Second day & Third day \\
\hline 1 & 19781.6 & 19452.2 & 19531.8 \\
\hline 2 & 19736.8 & 19300.7 & 19486.5 \\
\hline 3 & 19712.7 & 19269.9 & 19464.4 \\
\hline 4 & 19689.4 & 19307.7 & 19438.1 \\
\hline 5 & 19663.0 & 19266.7 & 19407.1 \\
\hline 6 & 19626.5 & 19165.7 & 19371.0 \\
\hline Pooled mean & 19481.8 & & \\
\hline Pooled RSD\% & $0.95 \%$ & & \\
\hline
\end{tabular}

Table 10. Analyst change effect against the second \& third analyst

\begin{tabular}{cccc}
\hline Replicate \# & First Analyst & Second Analyst & Third Analyst \\
\hline 1 & 19781.6 & 19661.9 & 19781.6 \\
2 & 19736.8 & 19679.5 & 19736.8 \\
3 & 19712.7 & 19659.5 & 19712.7 \\
4 & 19689.4 & 19632.2 & 19689.4 \\
5 & 19663.0 & 19613.2 & 19663.0 \\
6 & 19626.5 & 19582.6 & 19626.5 \\
Pooled mean & & 19680.5 & \\
Pooled RSD\% & & $0.28 \%$ & \\
\hline
\end{tabular}

Table 11. Column change effect against the second column

\begin{tabular}{ccc}
\hline Replicate \# & First Column & Second Column \\
\hline 1 & 19781.6 & 19214.0 \\
2 & 19736.8 & 19237.5 \\
3 & 19712.7 & 19202.7 \\
4 & 19689.4 & 19249.2 \\
5 & 19663 & 19252.1 \\
6 & 19626.5 & 19211.5 \\
Pooled mean & 19464.8 & \\
Pooled RSD $\%$ & $1.3 \%$ & \\
\hline
\end{tabular}

\subsection{Stability of solution}

The test solution was found to be stable in the auto-sampler within about 12 hours at room temperature with RSD \% equal to $1.1 \%$ as in Table 12 .

Table 12. Stability of solution

\begin{tabular}{cccccccc}
\hline$\#$ & 0 hour & 3 hours & 6 hours & 12 hours & Average P. As & STDEV & RSD \% \\
\hline Test P. A & 19359 & 19264.6 & 19025.7 & 18930.6 & 19145.0 & 200.3 \\
\hline
\end{tabular}

\subsection{Specificity and selectivity}

The peak of Cfm was well resolved from any other degradation peaks and any adjacent peak with a resolution of at least 8.15 as in Figure 4. So, the method was found to be specific and selective for Cfm determination. 


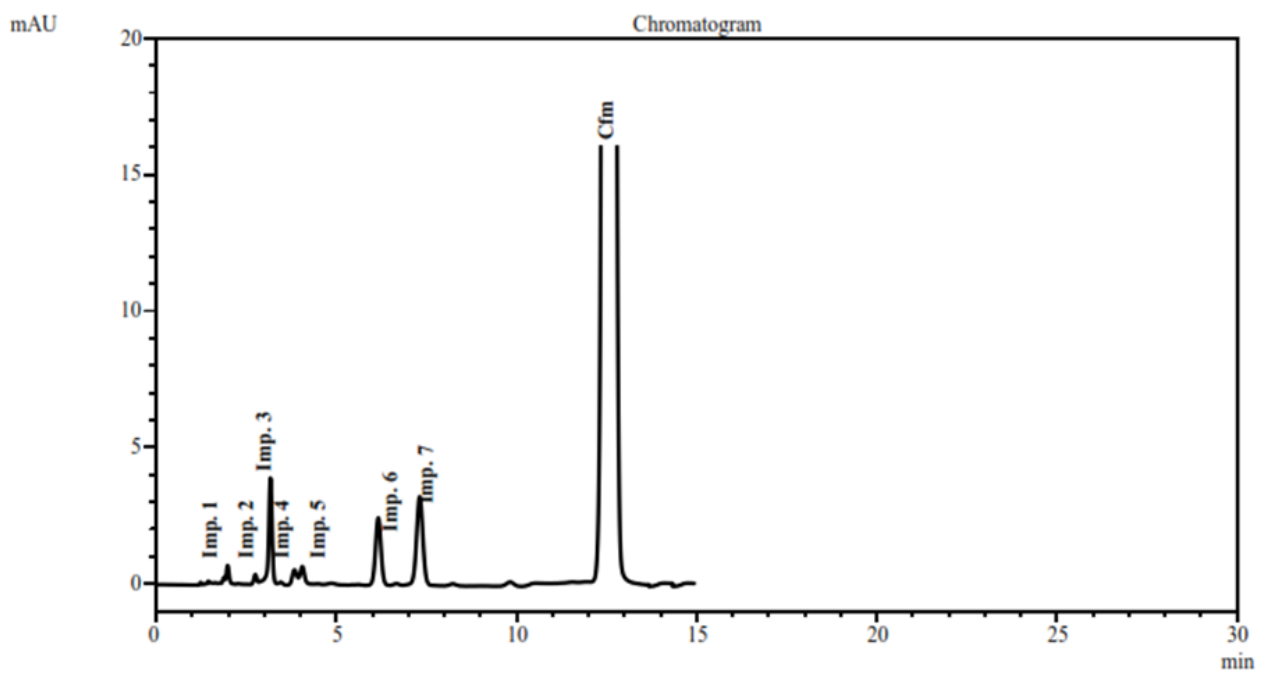

Figure 4. Effect of heating degradation; the chromatographic method uses a reversed-phase column BDS column (150 mm $\mathrm{x} 4.0 \mathrm{~mm} \times 5 \mu \mathrm{m})$. The mobile phase was prepared by mixing Methanol: Phosphate buffer $(1000 \mathrm{~mL}: 130 \mathrm{~mL})$ and the pH was adjusted to 6.15 at isocratic flow rate 1.0 $\mathrm{mL} / \mathrm{min}$ with PDA detector at $235 \mathrm{~nm}$, column oven adjusted at $30^{\circ} \mathrm{C}$ and injection volume $20 \mu \mathrm{L}$, target conc $1 \mu \mathrm{g} / \mathrm{mL} \mathrm{of} \mathrm{Cfm}$.

\subsection{Analysis of different human-finished pharmaceutical drugs}

The $\mathrm{Cfm}$ average assay results of Claforan $1 \mathrm{gm}$ vials (Sanofi) and Cefotax $1 \mathrm{gm}$ vials (Eipico) revealed good results; $[987 \mu \mathrm{g} / \mathrm{g}]$ and $[1021 \mu \mathrm{g} / \mathrm{g}]$ respectively from the labeled amount of Cfm active pharmaceutical ingredient.

\section{Conclusions}

The present study introduces a rapid, easy, economical and accurate method of $\mathrm{Cfm}$ analysis. The analysis run time takes about 15 minutes. The method revealed a good behavior as linear, repeatable, rugged, robust, specific, selective and as the resolution factor between Cfm peak and any adjacent peak at least anyway greater than 1.5. DL and QL also, evaluated and showed an appreciated and satisfying value as $35.5 \mathrm{ng} / \mathrm{mL}$ and $107.6 \mathrm{ng} / \mathrm{mL}$ respectively. So, the method of analysis is valid to use for $\mathrm{Cfm}$ traces determination. The validated method revealed good results for the practical application in the analysis of the finished product of sterile Claforan $1 \mathrm{gm}$ vials (Sanofi) and Cefotax $1 \mathrm{gm}$ vials (Eipico) assay.

\section{Compliance with ethical standards}

The author declares that he has no conflict of interest

No research involving human participants and/or animals was included in the study.

\section{Funding}

This research did not receive any specific grant from funding agencies in the public, commercial, or not-for-profit sectors.

\section{Acknowledgment}

The author presents great thanks to the Smart pharma company for supporting this study.

\section{References}

[1] Nanda R, Bhagwat V, Potawale S, et al. Development and validation of a HPTLC method for simultaneous densitometric analysis of cefotaxime sodium and sulbactam sodium as the bulk drugs and in the pharmaceutical form. Pharm Res. 2010; 3: 1667-1669.

[2] Robinson AM, Medlicott NJ, Ussher JE. The rapid detection of cefotaxime-resistant Enterobacteriaceae by HPLC. Future science OA. 2016; 2: FSO142. 
[3] Pehourcq F, Jarry C. Determination of third-generation cephalosporins by high-performance liquid chromatography in connection with pharmacokinetic studies. Journal of Chromatography A. 1998; 812: 159-178.

[4] Consortti L, Salgado H. Green method for quantification of sodium cefotaxime in lyophilized powder by infrared spectroscopy. Journal of Pharmaceutical Sciences Emerging Drugs. 2017; 5: 2-6.

[5] CH AK, Gurupadayya B, Sloka N. Determination and validation of cefadroxil, ceftriaxone and cefotaxime by using n-bromosuccinamide in human plasma and pharmaceutical dosage form. International Journal of Research in Pharmaceutical Sciences. 2011; 2: 206-212.

[6] Sayed RA, Hassan WS, El-Mammli MY, et al. A new extractive spectrophotometric method for the determination of gatifloxacin and cefotaxime sodium in pure and pharmaceutical dosage forms. Oriental journal of chemistry. 2012; 28: 639.

[7] Rageh AH, El-Shaboury SR, Saleh GA, et al. Spectophotometric method for determination of certain cephalosporins using 4-chloro-7-nitrobenzo-2-oxa-1, 3-diazole (NBD-Cl). Natural Science. 2010; 2: 828.

[8] Sayed RA, Hassan WS, El-Mammli M, et al. Spectrophotometric method for the determination of cefotaxime sodium and cefoperazone sodium in pure and pharmaceutical dosage forms. American Chemical Science Journal. 2013; 3: 514-525.

[9] Gh AB, Rezvani M, Roshanzamir S. Spectrophotometric complexation of cephalosporins with palladium (II) chloride in aqueous and non-aqueous solvents. Spectrochimica Acta Part A: Molecular Biomolecular Spectroscopy. 2012; 89: 317-321.

[10] Lalitha N. Development and validation of RP-HPLC method for estimation of Cefotaxime sodium in marketed formulations. Journal of basic clinical pharmacy. 2010; 1:26-28.

[11] Saranya CL, Thejaswini J, Gurupadayya B, et al. Simultaneous Determination of Cefotaxime Sodium and Paracetamol by LC-MS. IOSR J. Pharm. 2014; 4: 12-18.

[12] Iqbal MS, Bahari MB, Darwis Y, et al. An RP-HPLC-UV Method with SPE for Cefotaxime in All-in-One Total Parenteral Nutritional Admixtures: Application to Stability Studies. Journal of AOAC International. 2013; 96: 290294.

[13] Wang P, Yuan T, Hu J, et al. Determination of cephalosporin antibiotics in water samples by optimised solid phase extraction and high performance liquid chromatography with ultraviolet detector. International journal of environmental analytical chemistry. 2011; 91: 1267-1281.

[14] Samanidou VF, Tsochatzis ED, Papadoyannis IN. HPLC determination of cefotaxime and cephalexine residues in milk and cephalexine in veterinary formulation. Microchimica Acta. 2008; 160: 471-475.

[15] Al-Hakkani MF. Guideline of inductively coupled plasma mass spectrometry "ICP-MS": fundamentals, practices, determination of the limits, quality control, and method validation parameters. SN Applied Sciences. $2019 ; 1: 791$. https://doi.org/10.1007/s42452-019-0825-5.

[16] Al-Hakkani MF. A rapid, developed and validated RP-HPLC method for determination of azithromycin. SN Applied Sciences. 2019; 1: 222. https://doi.org/10.1007/s42452-019-0237-6.

[17] Al-Hakkani MF. Forced degradation study with a developed and validated RP-HPLC method for determination of cefpodoxime proxetil in the bulk and finished pharmaceutical products. Journal of the Iranian Chemical Society. 2019; 16: 1571-1578. https://doi.org/10.1007/s13738-019-01630-5.

[18] European Pharmacopoeia. Appendix III chromatographic separation techniques, Ph. Eur. method 2.2.46, 7th edition $17 ; 2013$.

[19] FDA, Analytical procedures, methods validation: chemistry, manufacturing and controls documentation, availability, Federal Reg. (Notices) 6552776 (2000).

[20] ICH Harmonized Tripartite Guidelines, Validation of Analytical Procedures: Text and Methodology, Q2(R1) . Switzerland, Geneva; 2005.

[21] Al-Hakkani MF. Biogenic copper nanoparticles and their applications: A review. SN Applied Sciences. $2020 ; 2: 505$. https://doi.org/10.1007/s42452-020-2279-1. 